and a bound annual cumulation. It will be sponsored by the Library Association and will index about 400 journals, many of which are not already abstracted or indexed. It will produce each issue within six weeks of the publication of the journals concerned. The price will be about 15 guineas. Further particulars, and a prospectus containing a specimen page, are obtainable from the Association at Chaucer House, Malet Place, London, W.C.1.

\section{Field Studies Council}

Trat the Field Studies Council is performing a real service to learming is again clearly brought out in its annual report for the year 1959-60 (Pp. $32+4$ plates. (London : Field Studies Council, 9 Devereux Court, W.C.2.) 1961). Between 1951 and 1960 the number of visitors to the centres has more than doubled and, in 1960, was well over 8,000. It is interesting that more than half the visitors went to study 'biologicel subjects', and more than 3,000 studied 'geographical and geological subjects'; only 315 students were concerned with the 'countryside and natural history subjects'. The figures reflect mounting pressure from grammar schools and training colleges, while the report indicates that the centres could have been filled many times over between March and Whitsuntide. During the year amenities at Slapton Ley were improved and the new geography block was completed at Dale Fort.

\section{The World Meteorological Organization : Events}

THE World Meteorological Organization has announced its schedule of conferences and symposia to be organized during the rest of 1961 : April 12-26, Commission for Hydrological Meteorology-first session (Washington); June-July, Regional Association III-South America-third session (Rio de Janeiro) ; August 6-12, international symposium on "Atmospheric Ozone and General Circulation", to be held in conjunction with the International Ozone Commission (Arosa); August 14-19, symposium on "Radiation", to be hold in conjunction with the Radiation Commission of the International Associa. tion of Meteorology and Atmospheric Physics (Vienna) ; September 18-October 2, Commission for Aerology-third session (Rome) ; October 2-7, symposium on "Climatic Changes", to be held in conjunction with Unesco (Rome). Further information can be obtained from the Secretariat, World Meteorological Organization, Geneva.

\section{The Night Sky in April}

Full moon occurs on April 1d. 05h. 48m. U.T., new moon on April 15d. $05 \mathrm{~h} .38 \mathrm{~m}$. and full moon on April 30d. $18 \mathrm{~h} .41 \mathrm{~m}$. The following conjunctions with the Moon take place: April 9d. 06h., Saturn $3^{\circ} \mathrm{S}$.; April 9d. 14h., Jupiter $3^{\circ}$ S.; April 18d. 13h., Aldebaran 0.4 $4^{\circ}$ S.; April 22 d. 05h., Mars $5^{\circ}$ N.; April $25 \mathrm{~d}$. 05h., Regulus $1^{\circ} \mathrm{N}$. In addition to these conjunctions with the Moon, Mercury is in conjunction with Venus on April 18d. 01h., Mercury being $9^{\circ} \mathrm{S}$., and Mars with Pollux on April 23d. 03h., Mars being $5^{\circ} \mathrm{S}$. Mercury is too close to the Sun for easy observation. Venus will be visible for a few days at the beginning of the month as a bright star low in the west after sunset, but later in the month it is too close to the Sun for observation. Mars sets at $2 \mathrm{~h}$. $50 \mathrm{~m}$., $2 \mathrm{~h} .20 \mathrm{~m}$. and $1 \mathrm{~h} .40 \mathrm{~m}$. on April 1,15 and 30 , respectively. Mars is an evening star, but conditions for observation are becoming less favourable. Its stellar magnitude on April 15 is $+1 \cdot 1$; its distance is rapidly increasing and its apparent diameter decreasing. Jupiter and Saturn are morning stars, both rising just over two hours before the Sun; conditions for observation are not favourable. There is one occultation of a star brighter than magnitude 6 during the month, observations being made at Greenwich: Aldebaran, disappearance April 18d. 12h. 24.3m., reappearance April 18d. 13h. $01.4 \mathrm{~m}$. The Lyrid meteors are active during April 20-22, the maximum being on April 22. The radiant is at R.A. $18 \mathrm{~h} .04 \mathrm{~m}$., Dec. $+33^{\circ}$, and conditions for observation are very favourable.

\section{Announcements}

Prof. Dragoslav Popovrc has been appointed director of the International Atomic Energy Agency's Safeguards Division, in succession to Mr. R. M. Smith (Canada). Prof. Popovic is at present at the Boris Kidric Institute of Nuclear Science at Vinca, near Belgrade, and has been professor of nuclear reactor engineering at the University of Belgrade since 1958.

DR. KARL F. MEYER, director emeritus and professor emeritus of the University of California's George Williams Hooper Foundation for Medical Research, has been awarded the Jessie Stevenson Kovalenko Medal of the U.S. National Academy of Sciences. The award has been made in recognition of Dr. Meyer's achievements as an investigator, teacher and administrator in medicine for more than half a century, and especially for his work on the role of animals as hosts for vectors of human disease.

ThE Worcester Foundation for Experimental Biology, Shrewsbury, Mass., with the aid of a grant from the Population Council, is continuing its postdoctoral programme for scientific training in repro. ductive physiology. Fellowships will be awardod to candidates possessing the Ph.D. or M.D. degrees, or thoir equivalents ; they will carry a stipend of 5,500 dollars per annum and will be for a twelve. month period. Application forms can be obtained from Dr. Celso-Ramon Garcie, at the Worcester Foundation, and should be returned not later than June 1.

THE British Hydromechanics Research Association is organizing an international meeting on "Fluid Sealing" at Grosvenor Hall, Ashford, Kent, during April 17-19. Further information can be obtained from Mr. H. Stephens, information officer, British Hydromechanics Research Association, South Road. Temple Fields, Harlow, Essex.

A symposrum on "The Water Relations of Plants" is being organized by the British Ecological Society, and will be held at the Imperial College of Science and Technology, London, during April 5-8. Further information can be obtained from Dr. F. H. White. head, Botany Department, Imperial College of Science and Technology, Prince Consort Road, London, S.W.7.

THE ninth annual general meeting and conference of the British Agricultural History Society is to be held at Seale Hayne Agricultural College, Newton Abbot, Devon, from the evening of April 5 until lunch-time April 7. Further information can be obtained from Mr. S. T. Morxis, 1 Courtenay Park, Newton Abbot, Devon. 